Available online at GSC Online Press Directory

GSC Biological and Pharmaceutical Sciences

e-ISSN: 2581-3250, CODEN (USA): GBPSC2

Journal homepage: https://www.gsconlinepress.com/journals/gscbps

(RESEARCH ARTICLE)

\title{
Responses of ornamental Mussaenda species stem cuttings to varying concentrations of naphthalene acetic acid phytohormone application
}

\author{
Ogbu Justin U. ${ }^{1 *}$, Okocha Otah I. ${ }^{2}$ and Oyeleye David A. ${ }^{3}$ \\ ${ }^{1}$ Department of Horticulture and Landscape technology, Federal College of Agriculture (FCA), Ishiagu 491105 Nigeria. \\ ${ }^{2}$ Department of Horticulture technology, AkanuIbiam Federal Polytechnic, Unwana Ebonyi state Nigeria. \\ 3 Department of Agricultural technology, Federal College of Agriculture (FCA), Ishiagu 491105 Nigeria
}

Publication history: Received on 28 August 2017; revised on 03 October 2017; accepted on 09 October 2017

https://doi.org/10.30574/gscbps.2017.1.1.0009

\begin{abstract}
This study evaluated the rooting and sprouting responses of four ornamental Mussaendas species (Flag bush) stem cuttings to treatment with varying concentrations of 1-naphthalene acetic acid (NAA). Species evaluated include Mussaenda afzelii (wild), M. erythrophylla, M. philippica and Pseudomussaenda flava. Different concentrations of NAA phytohormone were applied to the cuttings grown in mixed river sand and saw dust (1:1; v/v); and laid out in a 4 x 4 factorial experiment in completely randomized design (CRD; $r=4$ ). Results showed that increasing concentrations of NAA application slowed down emerging shoot bud in M. afzelii, P. flava, M. erythrophylla and M. philippica. While other species responded positively at some point to increased concentrations of the NAA applications, the $P$. flava showed retarding effect of phytohormone treatment on its number of leaves. However, M. afzelii, M. erythrophylla and M. philippica, showed marked boost in their number of roots (NR) with the NAA increased application. The $0.2 \%$ NAA treated cuttings gave highest mean NR (4.6 roots) per stem cutting followed by the cuttings that received $0.4 \%$ NAA treatment which gave 4.3 mean NR, all of which were significantly different $(\mathrm{p} \leq 0.05)$. In terms of species response to the phytohormone positive effect, $M$. philippica gave highest mean NR (6.1 roots), followed by $M$. afzelii and $M$. erythrophylla which had 3.8 and 3.4 roots per cutting respectively. Evidently, the study has contributed to the conservation and propagation of ornamental Mussaenda collections in addition to providing vital information towards domestication of the wild indigenous species Mussaenda afzelii.
\end{abstract}

Keywords: Domestication; Gardening; Mussaenda species; Ornamentals; Phytohormones; Propagation

\section{Introduction}

Ornamental Mussaenda species are known for their showy flowers and foliage they provide during much of the year in garden landscapes. The genus Mussaenda L. belongs to the Rubiaceae family, and widespread across West Africa through the Indian sub-continent, southern China and Southeast Asia [1]. There are more than 200 known species, but around ten species are used for cultivation, and three of these being broadly utilized for landscaping [2]. Alejandro et al. reported the detail taxonomical status of the Mussaendas and some closely related genus [3]. The ornamental Mussaendas blossom from November to May in the southern hemisphere and from May to November in the northern side of the equator, while numerous species can bloom lasting through the year in tropical atmospheres [4-5]. The Mussaendas used for landscapes are scrambling shrubs and range from 60 to $450 \mathrm{~cm}$ in height, depending upon the species. Some wild Mussaendas species can climb up to $9 \mathrm{~m}$ around trees; while in gardening they rarely reach that size.

\footnotetext{
*Corresponding author

E-mail address: ogbujugo@ gmail.com
} 
The leaves are opposite, bright to dark green and rounded elliptic. They are often pubescent (covered with short, fine hairs) and prominently veined [1-2]. Mussaendas are known for its low pollen fertility, poor fruit production and limited seed production [4,6]. Therefore, multiplication of the species are mostly by stem cutting taking from hard woods, semi-hard woods and sometimes from soft woods rooted in a rooting media under optimum nursery conditions; although some species/cultivars of potential aesthetic value are difficult to propagate by stem cuttings [78]. Phytohormones, especially auxins, have been used in plant nursery production to hasten root initiation in difficult to root species, increase the number and percentage of cutting rooted as well as quality of roots produced per cutting [9].

The present study aimed at contributing to the conservation of ornamental Mussaenda collections in addition to the domestication of the wild indigenous species (Mussaenda afzelii G. Don.). Specific objective of this study was to evaluate the rooting and sprouting response of four different ornamental Mussaendas stem cuttings to treatment with varying concentrations of 1-naphthalene acetic acid (NAA). The species evaluated include M. afzelli (wild species), M. erythrophylla Schumach and Thonn. (Red flag bush) (Figure 1) M. philippica A. Rich. (Pink flag bush or Queen of philipine) and Pseudomussaenda flava Verdc. (previously Mussaenda luteola- Dwarf mussaenda) (Figure 2). Unlike the three other species, M. afzelii has not been domesticated although its floriculture potential has been noted, but not yet tried [8].

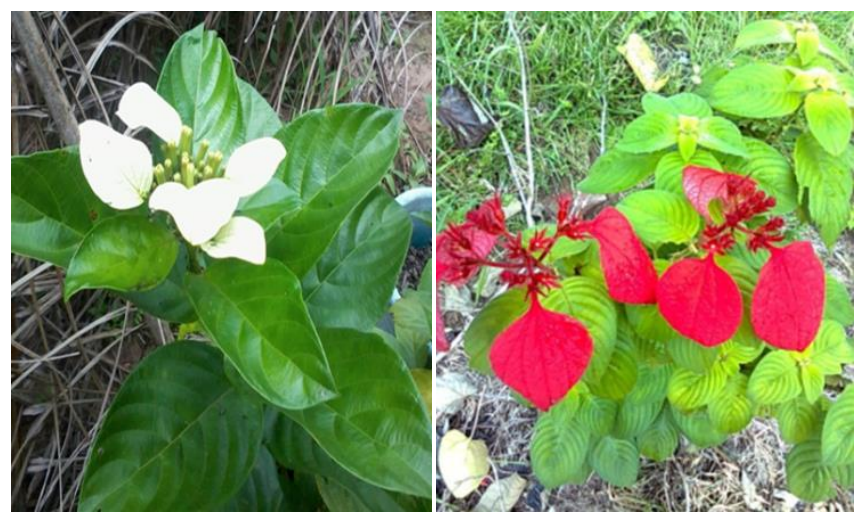

Figure 1 Mussaenda afzelii (left - grows wildly in Nigeria but with floriculture potentials for domestication) and Mussaenda erythrophylla (right - common garden plants)

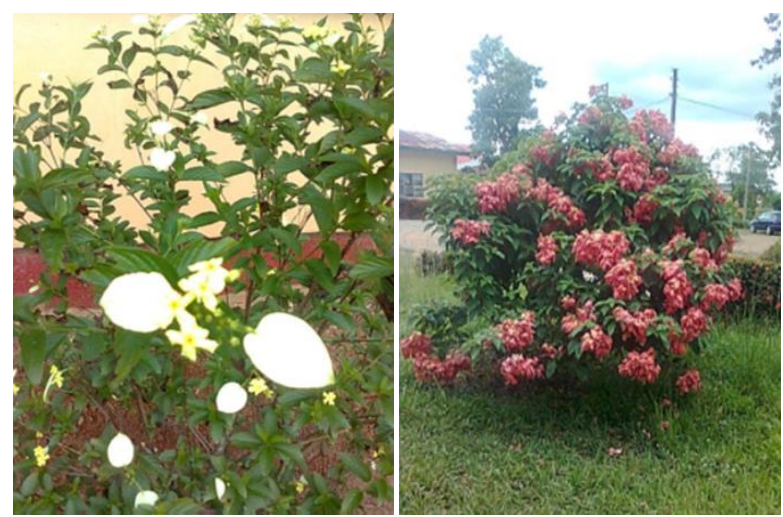

Figure 2 Mussaenda philippica (right) and Pseudomussaenda flava (left) are common ornamental Mussaenda plants grown in Nigeria's gardens

\section{Material and methods}

The study was carried out at floriculture nursery of the Department of Horticulture and Landscape technology, Federal College of Agriculture (FCA), Ishiagu Ebonyi State, Nigeria. The area lies along latitude $05^{\circ} 56^{\prime} \mathrm{N}$ and longitude $07^{\circ} 41^{\prime} \mathrm{E}$ in the derived savannah zone of Southeastern Nigeria. The mean annual rainfall for the area is $1350 \mathrm{~mm}$, which spreads from April to October or sometimes November, and average air temperature of $29^{\circ} \mathrm{C}$. Stem cuttings of 
M. erythrophylla, M. philippica and Pseudomussaenda flava were collected from their respective parent stands at floricultural garden of FCA, Ishiagu; while M. afzelii stem cuttings were obtained from wild at Ovunte Community in Ishiagu, Ebonyi State southeast Nigeria. The growth medium was prepared using mixed river sand and saw dust at the ratio of $1: 1$ by volume, and was filled into 64 plastic pots measuring $30 \mathrm{~cm}$ by $35 \mathrm{~cm}$ dimension; while different concentrations of NAA phytohormone namely: 0 (control), $0.1,0.2$, and $0.3 \%$ were used.

After the assembling of planting materials, the collected Mussaenda stem cuttings were cut into uniform size of $15 \mathrm{~cm}$ length and labeled with masking tape. Thereafter, the stem cuttings were carefully dipped into solution of the respective NAA concentrations for two minutes before planting. Each of the pot was planted with two stands of stem cutting of the test plants according to the various treatments. The experimental design used was $4 \times 4$ factorial experiments in completely randomized design (CRD) with two factor treatments and sixteen treatment combinations, replicated four times. The factors employed in this experiment included: 4 (Ornamental Mussaendas) $\mathrm{x} 4$ (concentrations of NAA). The following parameters were taken at four weeks after planting to assess the rooting and sprouting performance of the cuttings in the various treatments: number of sprouted buds, number of leaves, number of roots and root length (cm). Data collected were analyzed by use of analysis of variance (ANOVA); while mean separation was carried out using Fisher's Least Significant Difference (LSD) at 5\% probability level. Descriptive statistics was used where appropriate.

\section{Results and discussion}

The effect of NAA application and Mussaenda species on number of sprouted buds showed that increasing concentrations of the chemical solution slowed down emerging shoot growth (Table 1). This is not surprising, as the phytohormone action is targeted at boosting root growth and so energy for growth processes was mobilized more toward the root zone [9-10]. Thus, such phytohormone when used in this manner is otherwise known as rooting hormone. By this response, the 0\% NAA (control) treatment appeared to do better among all the species in terms of number of sprouted buds per cutting. The dwarf Mussaenda ( $P$. flava) stem cuttings showed least response to the phytohormone application at the various concentrations used. However, the combined treatment effect and interaction of the factors had significant effect $(p \leq 0.05)$ on the number of sprouted buds.

Table 1 Effect of phytohormone NAA application and Mussaenda species on number of sprouted buds

\begin{tabular}{llllll}
\hline \multirow{2}{*}{\multicolumn{1}{c}{ Species }} & \multicolumn{4}{c}{ NAA concentrations } & \multirow{2}{*}{ Species mean } \\
\cline { 2 - 5 } & $\mathbf{0 . 0}$ & $\mathbf{0 . 1 \%}$ & $\mathbf{0 . 2 \%}$ & $\mathbf{0 . 4} \%$ & \\
\hline Mussaenda afzelii & 2.3 & 1.0 & 1.5 & 2.0 & 1.7 \\
Pseudomussaenda flava & 2.5 & 1.0 & 1.0 & 1.0 & 0.8 \\
M. erythrophylla & 2.0 & 1.0 & 1.8 & 1.0 & 1.4 \\
M. philippica & 1.0 & 2.8 & 2.3 & 2.3 & 2.1 \\
NAA mean & 1.9 & 1.4 & 1.6 & 1.6 & \\
\hline
\end{tabular}

LSD (0.05) Treatment means $=1.03 ;$ LSD (0.05) Factors means (NAA \& Species) = ns; Interaction $=*$

Table 2 Effect of phytohormone NAA application and Mussaenda species on number of leaves

\begin{tabular}{|c|c|c|c|c|c|}
\hline \multirow{2}{*}{ Species } & \multicolumn{4}{|c|}{ NAA concentrations } & \multirow{2}{*}{ Species mean } \\
\hline & 0.0 & $0.1 \%$ & $0.2 \%$ & $0.4 \%$ & \\
\hline Mussaenda afzelii & 2.3 & 1.0 & 1.5 & 3.5 & 2.1 \\
\hline Pseudomussaenda flava & 3.5 & 1.0 & 1.0 & 1.0 & 1.6 \\
\hline M. erythrophylla & 3.3 & 1.0 & 3.3 & 1.0 & 2.1 \\
\hline M. philippica & 1.0 & 3.5 & 1.8 & 2.3 & 2.1 \\
\hline NAA mean & 2.5 & 1.6 & 1.9 & 1.9 & \\
\hline
\end{tabular}

LSD (0.05) Treatment means $=$ ns; LSD (0.05) Factors means $($ NAA \& Species) $=$ ns; Interaction $=*$ 
Number of leaves on the species stems cuttings showed similar response to phytohormone applications (Table 2). While other species responded positively at some point to the varying concentrations of the NAA applications, the $P$. flava showed retarding effect of phytohormone treatment (from 3.5 to 1.0 leaves).

Apart from P. flava stem cuttings that indicated no variation in both the control and hormone treated cuttings, the other three M. afzelii, M. erythrophylla and M. philippica, showed marked boost in their number of roots with the NAA application (Table 3). The $0.2 \%$ NAA treated cuttings gave highest mean number of root (4.6 roots) per stem cutting followed by the cuttings that received $0.4 \%$ NAA treatment which gave 4.3 mean number of roots $[7,11]$. In terms of species response to the phytohormone positive effect, $M$. philippica had highest mean number of roots (6.1 roots), followed by $M$. afzeliiand $M$. erythrophylla which had 3.8 and 3.4 roots per cutting respectively.

Table 3 Effect of phytohormone NAA application and Mussaenda species on number of roots

\begin{tabular}{llllll}
\hline \multirow{2}{*}{ Species } & \multicolumn{4}{c}{ NAA concentrations } & \multirow{2}{*}{ Species mean } \\
\cline { 2 - 5 } & $\mathbf{0 . 0}$ & $\mathbf{0 . 1 \%}$ & $\mathbf{0 . 2 \%}$ & $\mathbf{0 . 4} \%$ & \\
\cline { 2 - 5 } Mussaenda afzelii & 2.8 & 3.3 & 1.5 & 7.5 & 3.8 \\
Pseudomussaenda flava & 1.0 & 1.0 & 1.0 & 1.0 & 1.0 \\
M. erythrophylla & 2.8 & 1.0 & 8.5 & 1.0 & 3.4 \\
M. philippica & 1.0 & 8.8 & 7.0 & 7.5 & 6.1 \\
NAA mean & 1.9 & 3.5 & 4.6 & 4.3 & \\
\hline \multirow{2}{*}{ LSD (0.05) Treatment means } & $=4.22 ;$ LSD (0.05) Factors means (NAA \& Species) & 2.9.99; Interaction $=* *$
\end{tabular}

On root length, the $0.4 \%$ NAA treatment gave longest mean root length $(3.9 \mathrm{~cm})$, although this was not significantly different from the other concentrations (Table 4). Moreover, M. philippica maintained its most favorable positive response to NAA application among the species with regard to length of adventitious root produced (4.6 cm), more than other species. In the parameters assessed, the wild $M$. afzelii stem cuttings evidently showed amenability to application of NAA phytohormone for its enhanced multiplication and domestication.

Table 4 Effect of phytohormone NAA application and Mussaenda species on root length (cm)

\begin{tabular}{llllll}
\hline \multirow{2}{*}{ Species } & \multicolumn{4}{c}{ NAA concentrations } & \multirow{2}{*}{ Species mean } \\
\cline { 2 - 5 } & $\mathbf{0 . 0}$ & $\mathbf{0 . 1 \%}$ & $\mathbf{0 . 2 \%}$ & $\mathbf{0 . 4} \%$ & \\
\hline Mussaendaafzelii & 3.5 & 4.5 & 1.3 & 4.5 & 3.4 \\
Pseudomussaendaflava & 1.0 & 1.0 & 1.0 & 1.0 & 1.0 \\
M. erythrophylla & 3.0 & 1.0 & 3.8 & 1.0 & 2.2 \\
M. philippica & 1.0 & 6.3 & 5.5 & 5.8 & 4.6 \\
NAA mean & $2.1 \mathrm{~ns}$ & $3.2 \mathrm{~ns}$ & $2.9 \mathrm{~ns}$ & $3.9 \mathrm{~ns}$ & \\
\hline
\end{tabular}

LSD (0.05) Treatment means $=2.72 ;$ LSD (0.05) Factors means (NAA \& Species) = 1.93; Interaction = *

\section{Conclusion}

In the trial been reported, the NAA application at $0.2 \%$ concentration remarkably enhanced adventitious root production in the ornamental Mussaendas better than other concentrations and control treatments used. Wild $M$. afzelii proved amenable to NAA application for its enhanced propagation, thereby providing opportunity for further investigation of this species floriculture potentials and conservation. 


\section{Compliance with ethical standards}

\section{Acknowledgments}

The kind assistance received from Mr. Terdoo Haanongon of the Department of Horticulture and Landscape technology, Federal College of Agriculture (FCA), Ishiagu Ebonyi state Nigeria, his suggestions during the execution and in-house presentation of the research report were most appreciated.

\section{Disclosure of conflict of interest}

There is no conflict of interest among the authors.

\section{References}

[1] John MC and Joe G. (2014). Mussaendas for South Florida Landscapes. In: Extension, Institute of Food and Agricultural Science, University of Florida.

[2] Sheat WG and Schofield G. (1995). Complete Gardening in Southern Africa. Struik Publishers, Cape Town, 76.

[3] Alejandro GD, Razafimandimbison SG and Liede-Schumann S. (2005). Polyphyly of Mussaenda inferred from ITS and trnT-F data and its implication for generic limits in Mussaendeae (Rubiaceae). American Journal of Botany, 92(3), 544-557.

[4] Rosario TL.(1998). Ornamental Mussaendas of the Philippines. College of Agriculture, University of the Philippines Los Banõs College.

[5] Matthew IP and Karikari SK. (1990). Horticulture: Principles and Practices. Macmillan, Lagos, 184.

[6] Steentoft M. (1988). Flowering plants of West Africa. Cambridge University Press, Cambridge, 210 - 214.

[7] Chadha KL and Choudhury B. (2007). Ornamental horticulture in India. Indian Council of Agricultural Research (ICAR), New Delhi, 172 - 174.

[8] Ogbu J. (2011). Ornamental Mussaenda spp. for Nigeria's gardens and landscape environment. In Proceedings of the $45^{\text {th }}$ Annual Conference of the Agricultural Society of Nigeria (ASN), 316-319.

[9] Hartmann HT, Kester DE, Davies Jr FT and Geneve RL. (2007). Plant propagation: principles and practices. Prentice- Hall Inc., New Delhi, 7th ed., 293- 603.

[10] Chadha KL. (2009). Handbook of horticulture. Indian Council of Agricultural Research (ICAR), New Delhi, 76 82.

[11] Acquoah G. (2004). Horticulture: principles and practices. Prentice - Hall Press, New Delhi, 2nd ed., 316 - 356.

\section{How to cite this article}

Ogbu JU, Okocha OI and Oyeleye DA. (2017). Response of ornamental Mussaenda species stem cuttings to varying concentrations of naphthalene acetic acid phytohormone application. GSC Biological and Pharmaceutical Sciences, $1(1), 20-24$. 